\title{
Impact of Soil Moisture Depletion and Splitting the Recommended Nitrogen Fertilizer Rate on Water Requirements and Water use Efficiencies of Wheat Crop in North Delta
}

\author{
A.T. Beshara*, T.I. Borham ${ }^{* *}$, M.M. Saied ${ }^{* * *}$ and A.S. El- \\ Hassanin* \\ Natural Resources Department, "Institute of African Research \\ and Studies, ${ }^{* *}$ Soils Department, Faculty of Agriculture, Cairo \\ University and ${ }^{* * *}$ Soils, Water and Environment Research \\ Institute, Agricultural Research Center, Giza, Egypt.
}

\begin{abstract}
A FIELD experiment was conducted at Sakha Agric. Res. A Station Farm, Kafr El-Sheikh Governorate during the two successive seasons of 2009/2010 and 2010/2011. A split plot design with four replicates was used to investigate the effect of splitting the recommended $\mathrm{N}$-fertilizer rate under three levels of available soil moisture depletion on grain and straw yields, water requirements, as well as water use efficiency of wheat crop. Main plots were devoted to irrigation treatments $\left(I_{1}, 40 \% ; I_{2}, 55 \%\right.$ and $I_{3}$, $70 \%$ available soil moisture depletion, ASMD), whereas the sub-plots were assigned to splitting the recommended rate of urea fertilizer $\left(\mathrm{F}_{1}\right.$, 4-equal doses, $F_{2}, 3$-equal doses and $F_{3}, 2$-equal doses). The results indicated that the recorded values of water consumptive use were $1645.1,1528.0$ and $1449.8 \mathrm{~m}^{3} /$ fed in the first season for $\mathrm{I}_{1}, \mathrm{I}_{2}$ and $\mathrm{I}_{3}$, respectively. While, the corresponding values in the second season were $1682.1,1526.3$ and $1407.0 \mathrm{~m}^{3} / \mathrm{fed}$ for the same treatments, respectively. The obtained results revealed that the highest mean values of field water use efficiency (FWUE) in the first season (1.44, 1.34 and $1.31 \mathrm{~kg}$ grain $/ \mathrm{m}^{3}$ ) were recorded under $I_{1}, I_{2}$ and $I_{3}$ treatments, respectively, while in the second season, the corresponding values $\left(1.32,1.24\right.$ and $\left.1.19 \mathrm{~kg} / \mathrm{m}^{3}\right)$ were given by the above-mentioned treatments, respectively. Concerning the $\mathrm{N}$-fertilizer applied, the obtained results showed that the highest mean values of FWUE in the first season were $1.42,1.37$ and $1.27 \mathrm{~kg}$ grain $/ \mathrm{m}^{3}$ for $\mathrm{F}_{1}, \mathrm{~F}_{2}$ and $\mathrm{F}_{3}$, respectively, whereas in the second season, the corresponding values were $1.41,1.21$ and $1.12 \mathrm{~kg}$ grain $/ \mathrm{m}^{3}$ for the same ones. It can be concluded that the $40 \%$ depletion of ASMD and splitting the $\mathrm{N}$-fertilizer rate into 4 equal doses is the best treatment for wheat production in North Delta.
\end{abstract}

Keywords: Wheat yield, Nitrogen fertilizer, Soil moisture depletion, Water requirements and Water use efficiency.

Wheat (Triticum aestivum-L.) is the most important cereal crop in the world as a whole. Many countries around the world suffer from a shortage of its production, 
particularly the developing and natural resource-poor countries, where there are many factors that contribute to the emerge of this imbalance. The steady population increase at a high rate is the most important one, alongside others such as inadequate water resources, where water is the most important factor in any policy to increase agricultural productivity or arable land. So, with intensifying water shortage, adoption of deficit irrigation strategies is likely to increase around the world. Therefore, it was necessary to control and manage the available water supply to face the overuse problem and minimize water losses to improve irrigation efficiency, and to raise the productivity of the cultivable soils (Badawy, 2001).

It is noteworthy that Egypt - according to FAO's statistics (2008) - is the first largest importer of wheat in the world, where it imports more than $50 \%$ of the annual consumption. In order to eliminate the productivity gap and to offset the losses occurred during handling and storage, where the average annual consumption per capita ranges from 150 to $180 \mathrm{~kg}$.

The harvested area is slightly more than 3 million feddans, the average productivity is about 18 ardab per feddan (Ardab $=150 \mathrm{~kg}$ ) and the domestic production of wheat is about 7.866 million tones, in average, during the period from 2006-2010. While the annual consumption currently ranged from 13-14 million tons. Accordingly, removal or at least narrowing this gap has become a national target.

Therefore, to reduce the breadth of this gap, it should be planned for the best ways to manage the available limited natural resources (water and land) in each region, in line with the climatic conditions to raise the efficiency of their using, and maximize their revenue on behalf of farmers, for achieving the adage" More crop per drop". In addition to estimate the efficiencies of using the recommended amount of the major elements such as nitrogen, phosphorus and potassium. Saied (1986) concluded that wheat plant roots did not extract water from depth below $60 \mathrm{~cm}$, where it consumed about $74 \%$ of the stored water from the $30 \mathrm{~cm}$ surface layer, while the rest from the $30-60 \mathrm{~cm}$ layer. El-Refaie et al. (1988 a) pointed out that the water consumptive use (WCU) values were 1764, 1575 and 1192.8 $\mathrm{m}^{3} /$ fed for treatments of $25 \%, 50 \%$ and $75 \%$ depletion of available soil moisture, respectively.

Gad El-Rab et al. (1988) found that, maximum grain and straw yields were obtained when 6 or 5 irrigations were applied during different growth stages. Said (1989) found that the highest wheat grain yield was obtained with irrigation treatment at $50 \%$ depletion of available soil moisture and increasing level of $\mathrm{N}$ up to $80 \mathrm{~kg} / \mathrm{fed}$. In the same item, Sheikh and Gillani (1990) evaluated the impact of farmer's irrigation practices $\left(\mathrm{T}_{3}\right)$ on grain yield and WUE in relation to $40 \%\left(\mathrm{~T}_{1}\right)$ and $60 \%\left(\mathrm{~T}_{2}\right)$ available soil moisture depletion. The results showed that $\left(\mathrm{T}_{2}\right)$ produced higher grain yield and WUE than that of $\left(\mathrm{T}_{3}\right)$ because of the

Egypt. J. Soil Sci. 53, No.2 (2013) 
over irrigation. Also, at $60 \%$ depletion, the yield per unit of water was significantly higher than that of (T3). In general, with traditional irrigation practice, over irrigation may decrease the grain yield and WUE. In a field trail in Assiut, Egypt, with two cultivars of wheat fertilized by $100 \mathrm{~kg} \mathrm{~N} / \mathrm{fed}$ applied in one full dose, 2, 3 and 4 equal splits at three weeks after sowing, stem elongaion, heading and milk ripening stages. The results showed that applying 3 splits of $\mathrm{N}$ produced highest grain and straw yields (El-Desoky et al., 2000).

Naeem (2005) studied the response of some wheat cultivars to irrigation at different soil moisture depletion levels (SMD) and water requirement. Four wheat genotypes were subjected to irrigation at 50 and $70 \%$ SMD. The results showed that grain yield, harvest index and WUE were greater when irrigation was applied at $50 \%$ SMD and was reduced at $70 \%$ SMD. Persual of data that was given from a field trail with wheat in Peshawar, it was indicated that split application of $\mathrm{N}$-fertilizer increased grain yield than single application (Tariq Jan et al., 2007). The effect of different degrees and periods of water stress on winter wheat grain yield were studied in a field trail in China. The results indicated that appropriate reduction of the irrigation amount can increase water use efficiency (Lei Yam et al., 2010).

Mahamed et al. (2011) evaluated the effect of soil moisture depletion (SMD) at levels of 50,60 and $75 \%$ of available soil moisture on yield, yield components and WUE of winter wheat grown under semi arid conditions. They found that, the SMD levels significantly affected grain yield, dry matter, weight of 1000-kernels, spike length, plant height and WUE at each growth stage. The highest mean values of these parameters were recorded under $50 \%$ depletion of available soil moisture.

For that important goal, this research was conducted, which aims to evaluate the productivity of the unit area (feddan) for wheat crop under the influence of overlapping of two variables, the first was the conditions of irrigation process through different levels of soil moisture depletion as a mean to rationalize water consumption, while the second was to measure the efficiency of the used nitrogen fertilizer by splitting the recommended amount, to be added in number of equal doses at different times depending on irrigation dates of the different treatments which in turn, depends on the level of depletion of the available soil moisture .

\section{Material and Methods}

A field experiment was conducted during two successive seasons of 2009 / 2010 and 2010 / 2011 at Sakha Agric. Research Station Farm, Kafr El-Sheikh Governorate $\left(31^{\circ} 07^{-}\right.$latitude N. and $30^{\circ} 57^{-}$longitude E., 6 m altitude).

The aim of this study was to investigate the impact of different levels of soil moisture depletion and splitting nitrogen fertilizer levels on wheat productivity, water requirements and water use efficiency. 
The experimental field area $\left(3045 \mathrm{~m}^{2}\right)$ was divided into three equal homogenous longitudinal plots. The main plot area (without replicates) was about $238 \mathrm{~m}^{2}(28 \times 8.5 \mathrm{~m})$, these plots were separated from each other by proof tracks ( $1.5 \mathrm{~m}$ width) to avoid lateral leakage of water to the adjacent plots. These main plots were assigned to the irrigation treatments (different soil moisture depletion levels). In the same time, each main plot was divided into three equal sub plots $\left(76.5 \mathrm{~m}^{2}\right.$ for each) which have been allocated to fertilization treatments (splitting the recommended rate of nitrogen fertilizer). Four replicates were allocated for each treatment.

The experimental design was split plot design, main plots were devoted to irrigation treatments as follows:

$\mathrm{I}_{1}$ : Irrigation when $40 \%$ of available soil moisture was depleted (ASMD).

$\mathrm{I}_{2}$ : Irrigation when $55 \%$ of available soil moisture was depleted (ASMD).

$\mathrm{I}_{3}$ : Irrigation when $70 \%$ of available soil moisture was depleted (ASMD).

Whereas, the sub plots were assigned to splitting the recommended rate of nitrogen fertilizer (90 units for clay soils, i.e., about $193.5 \mathrm{~kg} \mathrm{~N}$ as urea $46.5 \%$ $\mathrm{N}$, per feddan) as follows:

$\mathrm{F}_{1}$ : Splitting $\mathrm{N}$ fertilizer into four equal doses. The first quarter dose $(3.5 \mathrm{~kg} / \mathrm{sub}$ plot) was added before sowing, while the second, third and fourth quarter were applied with successive irrigations.

$\mathrm{F}_{2}$ : Splitting $\mathrm{N}$ fertilizer into three equal doses. The first dose $(4.7 \mathrm{~kg} / \mathrm{sub}$ plot $)$ was added before sowing, while the second and third doses were applied with successive irrigations.

$\mathrm{F}_{3}$ : Splitting $\mathrm{N}$ fertilizer into two equal halves, the first half $(7.0 \mathrm{~kg} / \mathrm{sub}$ plot $)$ was added before sowing, while the second half was applied with the next irrigation.

Wheat grains variety Sakha 93 were sown on November 21, 2009 in the first season, and harvested in the second half of May 2010 after full maturity. While in the second season, wheat grains were sown on November 15, 2010 and harvested in the mid of May, 2011. Wheat seeds were sown by planter at a rate of $60 \mathrm{~kg}$ of seeds per feddan after adjusting the sowing depth at $2-3 \mathrm{~cm}$. Other chemical fertilizers for wheat as potassium sulphate $\left(48 \% \mathrm{~K}_{2} \mathrm{O}, 50 \mathrm{~kg} / \mathrm{fed}\right)$ and Ca-superphosphate $\left(15.5 \% \mathrm{P}_{2} \mathrm{O}_{5}, 150 \mathrm{~kg} / \mathrm{fed}\right)$ were applied according to the usual recommended rates in the concerned area. Soil samples were collected at depths namely $0-20,20-40$ and $40-60 \mathrm{~cm}$ before planting and after harvesting , air-dried, ground and passed through $2.0 \mathrm{~mm}$ sieve and preserved for analysis.

At harvest stage, plant samples were randomly collected from each sub plot, oven dried at $70^{\circ} \mathrm{C}$ and grounded using stainless steel equipments and preserved for analysis. Mechanical analysis (sand, silt and clay) was determined according to the pipette method as described by Dewis and Fartias (1970). Soil reaction (pH) was measured in 1: 2.5 (soil: water) suspension according to Jackson (1967). Total 
water soluble salts were measured by the electrical conductivity meter apparatus in soil paste extract (Richards, 1954). Soluble ions $\left(\mathrm{Na}^{+}, \mathrm{K}^{+}, \mathrm{Ca}^{++}, \mathrm{Mg}^{++}, \mathrm{CO}_{3}^{--}\right.$, $\mathrm{HCO}_{3}{ }^{-}$and $\mathrm{Cl}^{-}$) were determined according to Jackson (1967), and sulphate was calculated by the difference between the sum of soluble cations and anions. Organic matter content (O.M., \%) was determined according to Walkly and Black method as described by Hesse (1971). Soil bulk density was determined using cylindrical sharp edged samples. Each cylinder was pressed gently into the soil to the desired depth to obtain a known volume of the undisturbed soil. Samples were oven dried at $105{ }^{\circ} \mathrm{C}$ and the bulk density calculated as $\mathrm{g} / \mathrm{cm}^{3}$ (Vomocil, 1957). Field capacity (F.C.) and permanent wilting point (P.W.P) were determined by using pressure membrane method at 0.33 and 15 atm, respectively (Klute, 1986).

Data of some physical and chemical analysis of the experimental site are presented in Tables 1, 2 and 3.

TABLE 1. Some physical properties of the soil at the experimental site.

\begin{tabular}{|c|c|c|c|c|c|c|}
\hline $\begin{array}{c}\text { Soil } \\
\text { depth, } \\
\text { cm }\end{array}$ & \multicolumn{2}{|c|}{ Particle size distribution, \% } & \multirow{2}{*}{ Texture } & OM $\%$ & $\mathbf{C a C O}_{\mathbf{3}}$ \\
\cline { 2 - 4 } class & Sand & Silt & Clay & Clay & 1.58 & 2.46 \\
\hline $0-20$ & 18.8 & 32.7 & 48.5 & Clay & 1.51 & 2.38 \\
\hline $20-40$ & 16.6 & 33.2 & 50.2 & Clay & 1.17 & 2.10 \\
\hline $40-60$ & 14.9 & 37.2 & 47.9 & . \\
\hline
\end{tabular}

TABLE 2. Some chemical properties of the soil at the experimental site.

\begin{tabular}{|c|c|c|c|c|c|c|c|c|c|c|}
\hline \multirow{2}{*}{$\begin{array}{c}\text { Soil } \\
\text { depth, } \\
\text { cm }\end{array}$} & \multirow{2}{*}{$\begin{array}{c}\text { PH } \\
1: 2.5\end{array}$} & \multirow{2}{*}{$\begin{array}{c}\text { ECe, } \\
\text { dS / m }\end{array}$} & \multicolumn{4}{|c|}{ Soluble cations, meq / L } & \multicolumn{4}{|c|}{ Soluble anions, meq / L } \\
\hline & & & $\mathbf{N a}^{+}$ & $\mathbf{K}^{+}$ & $\mathrm{Ca}^{2+}$ & $\mathrm{Mg}^{2+}$ & $\mathrm{CO}_{3}{ }^{2-}$ & $\mathrm{HCO}_{3}^{-}$ & $\mathrm{Cl}^{-}$ & $\mathrm{SO}_{4}{ }^{2-}$ \\
\hline $0-20$ & 7.78 & 1.75 & 10.4 & 0.35 & 5.1 & 2.2 & - & 1.1 & 10.7 & 6.25 \\
\hline $20-40$ & 7.93 & 1.63 & 9.6 & 0.35 & 4.8 & 2.0 & - & 1.2 & 10.2 & 5.35 \\
\hline $40-60$ & 8.42 & 2.27 & 13.9 & 0.40 & 6.1 & 2.8 & - & 1.1 & 14.3 & 7.80 \\
\hline
\end{tabular}

TABLE 3. Soil moisture constants and bulk density of the soil at the experimental site.

\begin{tabular}{|c|c|c|c|c|}
\hline $\begin{array}{c}\text { Soil depth, } \\
\text { (cm) }\end{array}$ & $\begin{array}{c}\text { Field } \\
\text { capacity, } \\
\text { (\% vol.) }\end{array}$ & $\begin{array}{c}\text { Wilting point, } \\
\text { (\% vol.) }\end{array}$ & $\begin{array}{c}\text { Available } \\
\text { water, }(\%)\end{array}$ & $\begin{array}{c}\text { Bulk density, } \\
\mathbf{g} / \mathbf{c m}^{\mathbf{3}}\end{array}$ \\
\hline $0-15$ & 43.9 & 24.0 & 19.9 & 1.12 \\
\hline $15-30$ & 39.1 & 21.2 & 17.8 & 1.16 \\
\hline $30-45$ & 37.0 & 20.1 & 16.9 & 1.22 \\
\hline $45-60$ & 36.2 & 19.7 & 16.5 & 1.26 \\
\hline
\end{tabular}

Amounts of the applied irrigation water

The amounts of applied irrigation water were measured by using a set of cutthroat flumes $(\mathrm{CTF}, 20 \times 90 \mathrm{~cm}$ and $30 \times 90 \mathrm{~cm})$ according to Early (1975). It is 
most suitable for field conditions because of the flat, an extremely smooth bottom surface and vertical walls which avoids the silt obstruction problem and makes installation easy. The calibration formula is given as follows:

For free flow:

$$
\mathrm{Q}=\mathrm{C} \times(\mathrm{Ha})^{\mathrm{n}}
$$

where: $\mathrm{Q}=$ Discharge in cumecs $\left(1\right.$ cumecs $\left.=10 \mathrm{~m}^{3}\right)$.

$\mathrm{C}=$ Flow discharge coefficient $(=0.7473$ for $20 \times 90$ and 1.132 for $30 \times 90)$

$\mathrm{Ha}=$ Water head at upper stream gauge $(\mathrm{cm}$.$) .$

$\mathrm{n}=$ constant $(=1.843$ for both $20 \times 90$ and $30 \times 90)$.

For submerged flow : $\quad \mathrm{Q}=\mathrm{C}(\mathrm{Ha}-\mathrm{Hb})^{\mathrm{n}} /\left(-\log _{10} \mathrm{~S}\right)^{\mathrm{ns}}$

where: $\mathrm{C}=0.413$ for $20 \times 90$ and 0.625 for $30 \times 90$.

$\mathrm{Hb}=$ Water head at down stream gauge $(\mathrm{cm})$.

$\mathrm{ns}=1.483$ for CTF of $20 \times 90$ and $30 \times 90$.

$\mathrm{S}=$ Actual submergence fraction $(\mathrm{Hb} / \mathrm{Ha})$.

If $(\mathrm{Hb} / \mathrm{Ha})=<65 \%=$ free flow.

If $(\mathrm{Hb} / \mathrm{Ha})=>65 \%$ = submerged flow.

\section{Determination of soil moisture percentage}

Soil moisture samples were taken before and after each irrigation from each plot with soil sampler (Auger) at depths of $0-15,15-30,30-45$ and $45-60$ $\mathrm{cm}$. These samples were immediately transported in tightly closed aluminum cans, where they were weighed in the laboratory, then dried in oven at $105{ }^{\circ} \mathrm{C}$ for $24 \mathrm{hr}$ and reweighed to calculate their moisture content as described by Garcia (1978).

\section{Water consumptive use (WCU)}

The WCU by wheat plants was computed gravimetrically as a difference in soil moisture content in the soil samples taken before and after irrigation on oven dry basis. Water consumptive use $\left(\mathrm{m}^{3} / \mathrm{fed}\right)$ was calculated using the following equation (Israelson and Hansen, 1962):

$$
\mathrm{WCU}=\sum_{\mathrm{i}=1}^{\mathrm{i}=\mathrm{n}}\left\{\left[\left(\theta_{2}-\theta_{1}\right) \times \mathrm{D}_{\mathrm{bi}} \times \mathrm{d}_{\mathrm{i}} \times 4200\right] / 100\right\}
$$

where: $\quad$ WCU $=$ Water consumptive use $\left(\mathrm{m}^{3} / \mathrm{fed}\right)$.

$\theta_{2}=$ Soil moisture $(\%)$ after irrigation in the $\mathrm{i}^{\text {th }}$ layer .

$\theta_{1}=$ Soil moisture $(\%)$ before next irrigation in the $\mathrm{i}^{\text {th }}$ layer.

$\mathrm{D}_{\mathrm{bi}}=$ Bulk density $\left(\mathrm{g} / \mathrm{cm}^{3}\right)$ of the $\mathrm{i}^{\text {th }}$ layer

$\mathrm{d}_{\mathrm{i}}=$ Depth of the $\mathrm{i}^{\text {th }}$ layer, $\mathrm{m}$.

$\mathrm{i}=$ No. of soil layers, $\mathrm{n}=$ No. of irrigation.

Stored water in the effective root zone (SW)

Seasonal (SW) was calculated using the following equation:

$$
\mathrm{SW}=\sum_{\mathrm{i}=1}^{\mathrm{i}=\mathrm{n}}\left\{\left[\left(\theta_{2}-\theta_{1}\right) \times \mathrm{D}_{\mathrm{bi}} \times \mathrm{d}_{\mathrm{i}} \times 4200\right] / 100\right\}
$$

Egypt. J. Soil Sci. 53, No.2 (2013) 
where: $\theta_{2}=$ Soil moisture (\%) after irrigation in the $\mathrm{i}^{\text {th }}$ layer.

$\theta_{1}=$ Soil moisture $(\%)$ before irrigation in the $\mathrm{i}^{\text {th }}$ layer.

(i.e., directly, before and after the same irrigation).

Soil moisture extraction pattern (SMEP)

It was calculated according to Israelson and Hansen (1962) as follows:

SMEP $=$ SME per layer $/$ Total seasonal SME.

where:

SME per layer $=$ Soil moisture extracted for specific layer.

Total seasonal SME = Total of the SME for all layers.

Application efficiency of irrigation water (Ea)

Application efficiency is defined as a ratio, (\%), between the amount of stored water $\left(\mathrm{m}^{3} / \mathrm{fed}\right)$, and the amount of the applied water $\left(\mathrm{m}^{3} / \mathrm{fed}\right)$ as described by Downy (1970):

$$
\mathrm{Ea}=(\mathrm{Ws} / \mathrm{Wa}) \times 100
$$

where: Ws, Wa are the volumetric stored water and the volumetric applied water, respectively.

Field-water use efficiency (FWUE) and crop-water use efficiency (CWUE)

They were calculated according to Beshara (2012) as follows :

FWUE $=$ Modified dry grain yield $(\mathrm{kg} / \mathrm{fed}) / \mathrm{IWA}_{\mathrm{a}}\left(\mathrm{m}^{3} / \mathrm{fed}\right)$.

$\mathrm{CWUE}=$ Modified dry grain yield $(\mathrm{kg} / \mathrm{fed}) / \mathrm{WCU}_{\mathrm{a}}\left(\mathrm{m}^{3} / \mathrm{fed}\right)$. where:

$\mathrm{IWA}_{\mathrm{a}}=$ actual irrigation water applied.

$\mathrm{WCU}_{\mathrm{a}}=$ actual water consumptive use.

Modified dry grain yield $($ MDGY $)=$

$\{[$ (actual straw yield, ton/fed. $\times$ local market price of straw, LE/ton) /

(local market price of wheat grains, LE/ton)] + actual grain yield $\} \times 0.89^{*}$.

The following parameters for wheat crop were determined:

a) Total yield: The harvested plants were weighed and the total yield was calculated as $\mathrm{kg} / \mathrm{fed}$.

b) Grain yield: The grains of each plot were collected from harvested plants and weighed. The grain yield was expressed as $\mathrm{kg} / \mathrm{fed}$.

c) Straw yield: It was calculated by subtracting the grain yield from the total yield in $\mathrm{kg} /$ fed.

\section{Results and Discussion}

Soil moisture extraction patterns for wheat crop as affected by different soil moisture depletion

Soil moisture extraction percentages in the upper $60 \mathrm{~cm}$ soil depth are presented in Table 4 and Fig. 1 and 2.

"Modified grain yield $\times 0.89=$ Modified dry grain yield .

$0.89=$ constant for the soft wheat. 
The results revealed that most of the consumed water by wheat roots was removed from the soil surface layers. Therefore, the highest percentage of the moisture uptake by wheat roots occurred at the surface layer $(15 \mathrm{~cm})$ which was found to be 34.72, 38.19 and 39.05\% in the first season, and 34.12, 33.47 and $36.73 \%$ in the second one under $70 \%, 55 \%$ and $40 \%$ depletion of available soil moisture, respectively. This means that wheat plants in treatment $\mathrm{I}_{1}(40 \%$ ASMD) extracted water from the upper foot more than treatments $I_{2}$ and $I_{3}$, respectively. These results are similar to that obtained by Saied (1986). The results also showed that the moisture extraction patterns were similar for all treatments in the two growing seasons. This mean that wheat roots extracted water from shallow soil layers during the early stages of growth, and then moisture extraction extended vertically to the lowest depths until most of the available moisture were extracted. It can be concluded that about $67.79 \%$ of the water used by wheat was obtained from the surface $30 \mathrm{~cm}$ soil layer and about $32.21 \%$ from the sub surface soil layers $(30-60 \mathrm{~cm})$.

On the other hand, the results showed that wheat roots under more available moisture soil condition $\left(\mathrm{I}_{1}, 40 \%\right.$ ASMD) extracted large amount of water (39.05 $\%)$ from the surface soil layer $0-15 \mathrm{~cm}$ depth, and a little amounts of water $(12.68 \%)$ from the deepest soil layer of $45-60 \mathrm{~cm}$. While, under drier treatment $\left(\mathrm{I}_{3}, 70 \%\right.$ ASMD), the consumed water was $34.72 \%$ and $16.15 \%$ from the surface layer $(0-15 \mathrm{~cm})$ and the lowest layer $(45-60 \mathrm{~cm})$, respectively in the first season. The same tendency was found in the second season, where in $I_{1}$ a large amount of water $(36.73 \%)$ was extracted from $(0-15 \mathrm{~cm})$ layer and a little amount $(12.75 \%)$ was extracted from the deepest layer $(45-60 \mathrm{~cm})$. While with $\mathrm{I}_{3}$, a less amount of soil moisture $(34.12 \%)$ was extracted from surface layer $(0-15 \mathrm{~cm})$ and $15.95 \%$ from the deepest layer $(45-60 \mathrm{~cm})$. This means that wheat roots are penetrate soil profile and extend for more depth under dried soil conditions to obtain their needs of water.

TABLE 4. Soil moisture (\%) extracted by wheat roots from different layers as affected by irrigation treatments during 2009/2010 and 2010/2011 growing seasons.

\begin{tabular}{|c|c|c|c|c|c|c|}
\hline \multirow{3}{*}{$\begin{array}{c}\text { Soil depths, } \\
\text { cm }\end{array}$} & \multicolumn{5}{|c|}{$\mathbf{2 0 0 9}$ / 2010 } & \multicolumn{3}{c|}{$\mathbf{2 0 1 0} / \mathbf{2 0 1 1}$} \\
\cline { 2 - 7 } & \multicolumn{3}{|c|}{ Irrigation treatments at different depletion levels of available soil moisture } \\
\cline { 2 - 7 } & $\mathrm{I}_{1}, 40 \%$ & $\mathrm{I}_{2}, 55 \%$ & $\mathrm{I}_{3}, 70 \%$ & $\mathrm{I}_{1}, 40 \%$ & $\mathrm{I}_{2}, 55 \%$ & $\mathrm{I}_{3}, 70 \%$ \\
\hline $0-15$ & 39.05 & 38.19 & 34.72 & 36.73 & 33.47 & 34.12 \\
\hline $15-30$ & 28.74 & 28.23 & 27.47 & 28.16 & 28.39 & 27.32 \\
\hline $30-45$ & 19.53 & 19.91 & 21.66 & 22.36 & 22.82 & 22.61 \\
\hline $45-60$ & 12.68 & 13.67 & 16.15 & 12.75 & 15.32 & 15.95 \\
\hline
\end{tabular}

Egypt. J. Soil Sci. 53, No.2 (2013) 


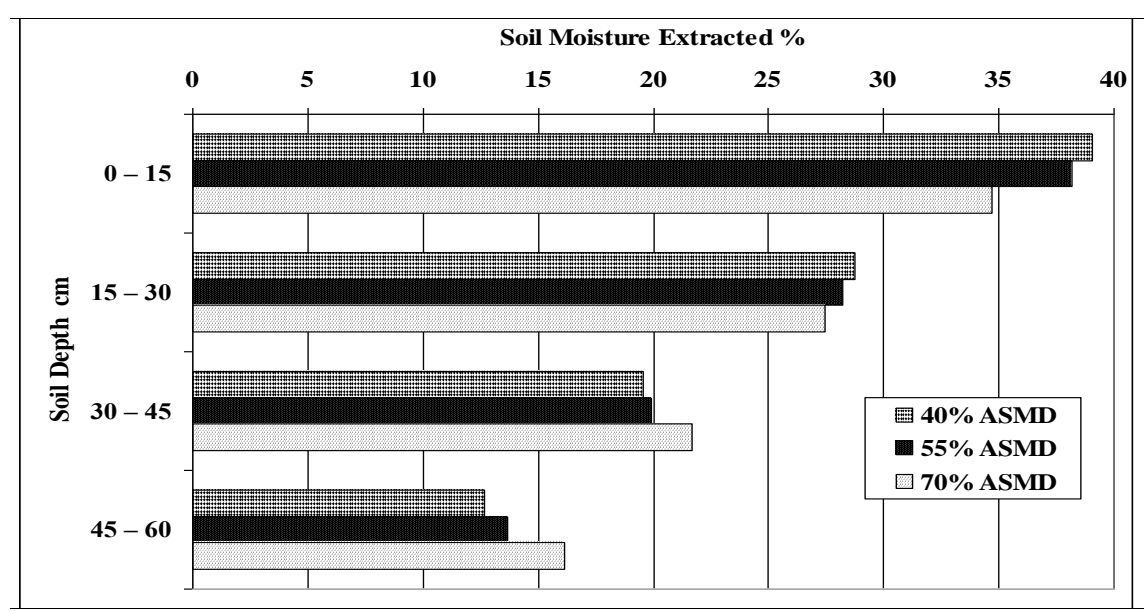

Fig. 1. Soil moisture extracted percentage by wheat roots from different soil layers as affected by different irrigatin treatments (2009/2010).

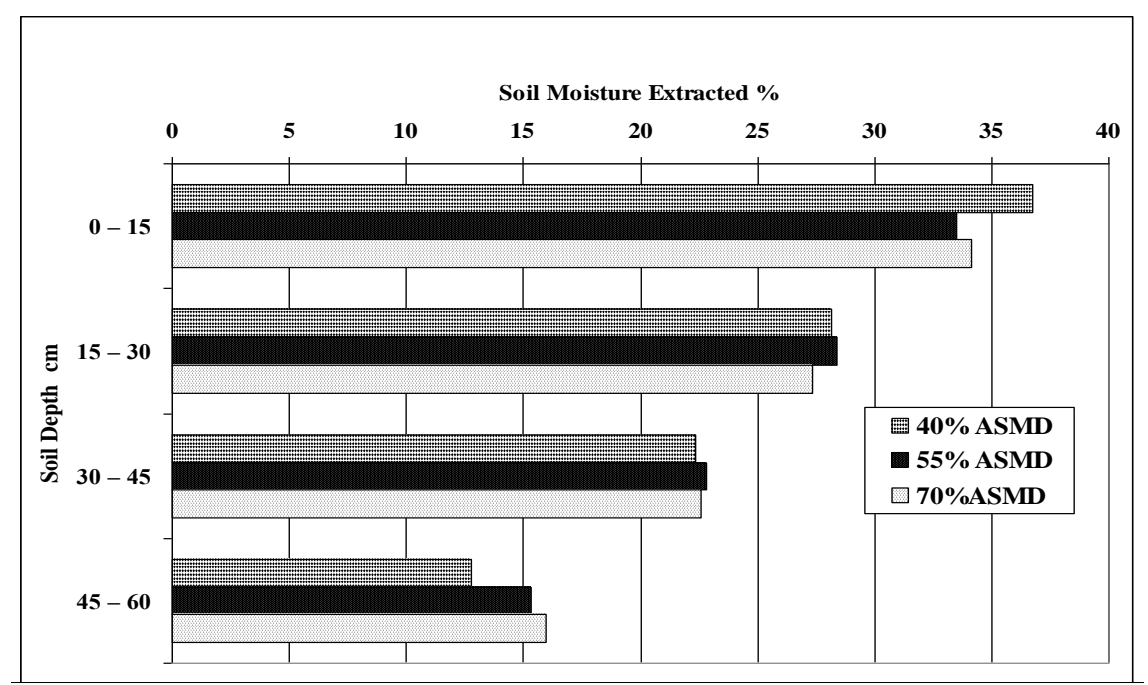

Fig. 2. Soil moisture extracted percentage by wheat roots from different soil layers as affected by different irrigatin treatments (2010/2011).

Actual water consumptive use $\left(\mathrm{m}^{3} / \mathrm{fed}\right)$ by wheat plants as affected by different soil moisture depletion levels

The results presented in Table 5 showed that the $\mathrm{I}_{1}$ treatment (40\% ASMD) was superior to the $\mathrm{I}_{2}$ treatment (55\% ASMD), which in turn was superior to the $\mathrm{I}_{3}$ treatment (70\% ASMD) in water consumptive use by wheat plants in both growing seasons. It can be concluded that more available soil moisture content enhance the plant roots system to uptake most or all of its required water. As 
shown in Table 5, the recorded values of water consumptive use were 1645.2, 1528.0 and $1449.8 \mathrm{~m}^{3} / \mathrm{fed}$ in the first season. While, the corresponding values in the second season were $1682.1,1526.3$ and $1407.0 \mathrm{~m}^{3} /$ fed for $\mathrm{I}_{1}, \mathrm{I}_{2}$ and $\mathrm{I}_{3}$, respectively. The obtained results agreed with those reported by El-Refai et al. (1988a).

TABLE 5. Actual water consumptive use by wheat plants as affected by different soil moisture depletion levels in both growing seasons.

\begin{tabular}{|c|c|c|c|c|c|c|}
\hline \multirow{3}{*}{ Season } & \multirow{3}{*}{$\begin{array}{l}\text { Irrigation } \\
\text { treatments }\end{array}$} & \multicolumn{4}{|c|}{ Actual water consumptive use, $\left(\mathbf{m}^{3} / \mathbf{f e d}\right)$} & \multirow{3}{*}{ Total } \\
\hline & & \multicolumn{4}{|c|}{ Soil depths, $\mathrm{cm}$} & \\
\hline & & $0-15$ & $15-30$ & $30-45$ & $45-60$ & \\
\hline \multirow{3}{*}{$2009 / 2010$} & $\mathrm{I}_{1}$ & 615.7 & 469.1 & 335.6 & 224.7 & 1645.1 \\
\hline & $\mathrm{I}_{2}$ & 558.6 & 427.6 & 316.7 & 225.1 & 1528.0 \\
\hline & $\mathrm{I}_{3}$ & 479.6 & 393.1 & 325.9 & 251.2 & 1449.8 \\
\hline \multirow{3}{*}{ 2010/2011 } & 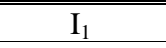 & 590.9 & 469.1 & 391.9 & 230.2 & 1682.1 \\
\hline & $\mathrm{I}_{2}$ & 486.8 & 427.6 & 361.6 & 250.3 & 1526.3 \\
\hline & $\mathrm{I}_{3}$ & 457.4 & 379.3 & 330.1 & 240.2 & 1407.0 \\
\hline
\end{tabular}

Amounts of the applied water to wheat crop

The values of applied water under different soil moisture depletion treatments in the two growing seasons are presented in Table 6 . The amounts of the applied water were $2229.4,2169.8$ and $2064.2 \mathrm{~m}^{3} /$ fed for $\mathrm{I}_{1}, \mathrm{I}_{2}$ and $\mathrm{I}_{3}$ treatments in the first season, respectively, while in the $2^{\text {nd }}$ season the corresponding values were $2336.4,2215.3$ and $2101.9 \mathrm{~m}^{3} / \mathrm{fed}$, for the same stated treatments. It was noticed that irrigation at $40 \%$ depletion received the highest amount of the applied irrigation water, whereas the lowest one was recorded with irrigation at $70 \%$ depletion of available soil moisture in the two growing seasons.

\section{Amounts of stored water}

Stored water in the effective root zone is one of the most important criteria which used to describe the field irrigation efficiency. The amounts of stored water in the effective root zone of wheat crop are presented in Table 6. The stored amounts were 1701.4, 1588.0 and $1480.5 \mathrm{~m}^{3} / \mathrm{fed}$. in the first season. While in the second season, these values were $1858.1,1709.4$ and $1612.8 \mathrm{~m}^{3} / \mathrm{fed}$ for the $I_{1}, I_{2}$ and $I_{3}$ stated treatments, respectively. The results indicated that, the highest amount of stored water was obtained under irrigation at $40 \%$ depletion of available soil moisture, while the lowest amount of stored water was obtained when $70 \%$ of available soil moisture was depleted.

\section{Application water efficiency $(\mathrm{Ea})$}

The results showed in general that values of (Ea) increase as the amount of the total applied water decrease. The calculated values of (Ea) for different soil moisture depletion levels are presented in Table 6. These values showed a pronounce decline in water application efficiency with increasing soil moisture

Egypt. J. Soil Sci. 53, No.2 (2013) 
stress up to $70 \%$ ASMD. Thus the application water efficiencies were found to be $76.3,73.2$ and $71.7 \%$ for $\mathrm{I}_{1}, \mathrm{I}_{2}$ and $\mathrm{I}_{3}$, respectively in the first season. While in the second one, the corresponding values were 79.5, 77.2 and $76.7 \%$, for the same stated treatments. It can be noticed that the highest values of water application efficiency $(76.3 \%$ and $79.5 \%)$ were obtained under $\mathrm{I}_{1}$ treatment (40\% ASMD) in both growing seasons, followed by $\mathrm{I}_{2}$ treatment (55\% ASMD). Whereas, the lowest values of $(\mathrm{Ea})$ were obtained with $\mathrm{I}_{3}$ treatment $(70 \%$ ASMD) in both seasons.

The highest value of water application efficiency under $I_{1}$ treatment may be due to uniform water distribution along the border irrigation and increasing the number of irrigation during the plant lifetime that resulted in increasing the stored water in the effective root zone of wheat. These findings are in harmony with those recorded by Abou El-Soud (2009).

TABLE 6. Amount of applied water to wheat plants, stored water and application water efficiency as affected by different soil moisture depletion in two growing seasons.

\begin{tabular}{|c|c|c|c|}
\hline \multirow{2}{*}{$\begin{array}{c}\text { Soil moisture } \\
\text { depletion }\end{array}$} & $\begin{array}{c}\text { Applied water, } \\
\mathbf{m}^{\mathbf{3}} / \mathbf{f e d}\end{array}$ & $\begin{array}{c}\text { Stored water, } \\
\mathbf{m}^{\mathbf{3} / \mathbf{f e d}}\end{array}$ & $\begin{array}{c}\text { Application water } \\
\text { efficiency, \% }\end{array}$ \\
\cline { 2 - 4 } & \multicolumn{3}{|c|}{$2009 / 2010$ growing season } \\
\hline $\mathrm{I}_{1}, 40 \%$ & 2229.4 & 1701.4 & 76.3 \\
\hline $\mathrm{I}_{2}, 55 \%$ & 2169.8 & 1588.0 & 73.2 \\
\hline $\mathrm{I}_{3}, 70 \%$ & 2064.2 & 1480.5 & 71.7 \\
\hline $\begin{array}{c}\text { Soil moisture } \\
\text { depletion }\end{array}$ & \multicolumn{3}{|c|}{$2010 / 2011$ growing season } \\
\hline $\mathrm{I}_{1}, 40 \%$ & 2336.4 & 1858.1 & 79.5 \\
\hline $\mathrm{I}_{2}, 55 \%$ & 2215.3 & 1709.4 & 77.2 \\
\hline $\mathrm{I}_{3}, 70 \%$ & 2101.9 & 1612.8 & 76.7 \\
\hline
\end{tabular}

Effect of different soil moisture depletion and splitting nitrogen fertilizer levels on wheat grains and straw yields

The results in Table 7 show that the soil moisture depletion and splitting nitrogen fertilizer levels had a highly significant effect on grain and straw yields of wheat crop in the first and second seasons. The grain yield decreased significantly with increasing soil moisture depletion levels from $40 \%$ to $55 \%$ and $70 \%$. The relative decreases in grain yield in the first season were 7.25 and $14.49 \%$, while in the second one, the reductions in grain yield were 10.65 and $18.97 \%$ for irrigation at $55 \%$ and $70 \%$ ASMD as compared to irrigation treatment at $40 \%$ ASMD. Concerning wheat straw yield, the results indicated that there was a highly significant effect of the tested variables during the two seasons of study. The mean values recorded a decrease in straw yield by about 14.73 and $18.11 \%$ in the first season, while in the second season; straw yields were 11.26 and $18.41 \%$ less for irrigation treatments at $55 \%$ and $70 \%$ ASMD 
as compared to irrigation at $40 \%$ ASMD. The increase in the yields (grains \& straw) under $40 \%$ ASMD may be due to increase leaf area, spike length and an increase in the period for which the crop remained green. It also resulted in increasing efficiency of capturing radiation energy and consequently more dry matter production.

Splitting nitrogen fertilizer rate had a highly significant effect on grain and straw yields in both seasons. The results in Table 7 show that the grain yield of wheat significantly increased with splitting nitrogen rate into equal four doses $\left(\mathrm{F}_{1}\right)$. The relative decreases in grain yield were $3.30 \%$ and $6.14 \%$ in the first season and 13.66 and $18.92 \%$ in the second season for $\mathrm{I}_{2}$ and $\mathrm{I}_{3}$, respectively as compared to $\mathrm{I}_{1}$. Also, splitting nitrogen rates had a highly significant effect on straw yield in the first and second seasons. Splitting nitrogen rates into four equal doses $\left(\mathrm{F}_{1}\right)$ led to increase in the straw yield by 5.41 and $14.69 \%$ over $\mathrm{F}_{2}$ and $\mathrm{F}_{3}$, respectively in the first season, while in the second season, these increments were 13.69 and 23.63 $\%$ for the same treatments, respectively. The dry weight of plant organs is also significantly increased. The influence of interaction between soil moisture depletion and splitting nitrogen rates on grain and straw yields were significant in the first season. While in the second season, there was insignificant effect of interaction between them. It can be concluded that the interaction between $I_{1} \times F_{1}$ achieved the highest grain and straw yields in both seasons.

TABLE 7. Wheat yields (ton/fed) as affected by different soil moisture depletion and splitting nitrogen fertilizer levels in the studied seasons.

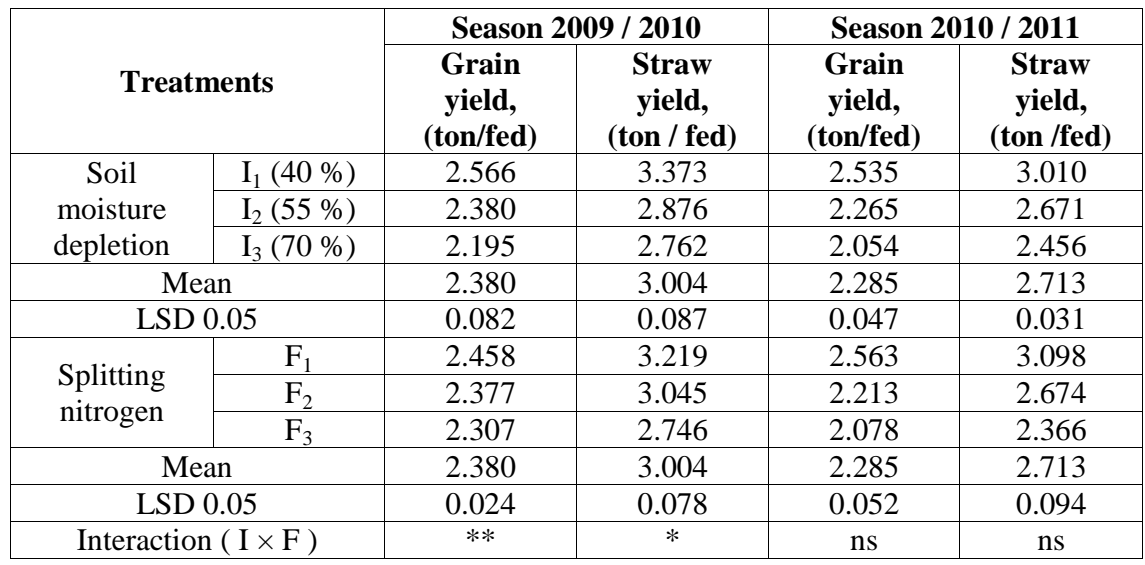

Water use efficiencies (WUE)

Water use efficiency reflects the ability of wheat plants to convert the water uptake to crop yield. Therefore, irrigation efficiency is a measure of the effectiveness of irrigation to raise the crop yield (Pitts, 1997). WUE is expressed as a mean of the productivity, in kilogram, per unit of water used in cubic meter, $\left(\mathrm{kg}\right.$ grain $/ \mathrm{m}^{3}$.

Egypt. J. Soil Sci. 53, No.2 (2013) 
The values of field and crop water use efficiencies during the two growing seasons of wheat crop as affected by different soil moisture depletion and splitting nitrogen fertilizer are presented in Table 8 and illustrated in Fig. 3 and 4. The obtained results revealed that the highest mean value of FWUE (1.44 kg grain $/ \mathrm{m}^{3}$ ) was recorded under $I_{1}$ treatment (40\% ASMD), followed by $\left(1.34 \mathrm{~kg} / \mathrm{m}^{3}\right)$ for $\mathrm{I}_{2}$ treatment (55 \% ASMD). Meanwhile, the lowest mean value $\left(1.31 \mathrm{~kg} / \mathrm{m}^{3}\right)$ was given by $\mathrm{I}_{3}$ treatment $(70 \%$ ASMD) in the first season, while in the second season; the corresponding values were $1.32,1.24$ and $1.19 \mathrm{~kg} / \mathrm{m}^{3}$ for the abovementioned treatments, respectively.

It was observed that the splitting of the recommended amount of $\mathrm{N}$-fertilizer into 4 equal increments, enhanced the value of FWUE more than splitting $\mathrm{N}$ fertilizer into two or/and three increments. Concerning the crop water use efficiency (CWUE), the results presented in Table 8 and Fig. 3 and 4 revealed the same tendency in both growing seasons, either between or within treatments. As the depletion level of available soil moisture decrease, the CWUE values increase. The results also indicate that the highest mean values (1.95 and 1.83 $\mathrm{kg} / \mathrm{m}^{3}$ ) were obtained under $I_{1}$ treatment in both growing seasons, respectively. While, the lowest mean values $\left(1.87\right.$ and $\left.1.78 \mathrm{~kg} / \mathrm{m}^{3}\right)$ were found under $\mathrm{I}_{3}$ treatment in the two growing seasons, respectively. It can be concluded that the values of CWUE under $F_{1}$ treatment (splitting the recommended rate of nitrogen fertilizer into four equal doses) are superior to $F_{2}$ and $F_{3}$ treatments in both seasons. This result may by attributed to that the increase of available water resulted in an increase of grain yield more than the increase of water stress, this in turn, led to raise the efficient use of irrigation water by the plants. Therefore, it can be concluded that the interaction between irrigation at $40 \%$ ASMD and splitting nitrogen fertilizer rate into four equal doses achieved the highest values of field and crop water use efficiencies. Generally, these findings are similar to those reported by Morsi (2005) and Abou El-Soud (2009) .

\section{Conclusion}

From the results of this study, it could be concluded that

1. The $40 \%$ depletion of available soil moisture content is the preferable irrigation treatment that should be applied under the same experimental conditions (that is mean for farmers; about six irrigations should be added during the growing season with interval duration of four weeks between each other).

2. Splitting the recommended rate of the $\mathrm{N}$-fertilizer ( $90 \mathrm{~N}$-units / fed) into four equal doses to be applied during the plant lifetime, the first before sowing and the rest should be applied directly before each of the next successive irrigations. 
TABLE 8. Water efficiencies of wheat crop as affected by different soil moisture depletion and splitting $\mathrm{N}$-fertilizer in 2009 / 2010 and 2010 / 2011 growing seasons.

\begin{tabular}{|c|c|c|c|c|c|c|c|c|}
\hline 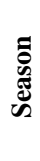 & \multicolumn{2}{|c|}{ Treatment } & $\begin{array}{c}\text { Modified } \\
\text { grain yield, } \\
\text { (kg/fed) }\end{array}$ & $\begin{array}{c}\text { Modified } \\
\text { dry grain } \\
\text { yield**, } \\
\text { (kg / fed) } \\
\text { (1) }\end{array}$ & $\begin{array}{c}\text { Total } \\
\text { water } \\
\text { applied, } \\
\left(\mathbf{m}^{3} / \mathbf{f e d}\right) \\
(2)\end{array}$ & $\begin{array}{c}\text { Actual water } \\
\text { consumptive } \\
\text { use, }\left(\mathrm{m}^{3} / \text { fed }\right) \\
\text { (3) }\end{array}$ & $\begin{array}{c}\text { FWUE, } \\
\left(\mathrm{kg} / \mathrm{m}^{3}\right) \\
(1 / 2)\end{array}$ & $\begin{array}{c}\text { CWUE, } \\
\left(\mathrm{kg} / \mathrm{m}^{3}\right) \\
(1 / 3)\end{array}$ \\
\hline \multirow{12}{*}{ 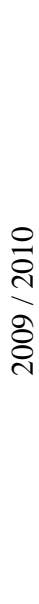 } & \multirow{3}{*}{$\begin{array}{l}\mathrm{I}_{1}, \\
(40 \\
\%)\end{array}$} & $\mathrm{F}_{1}$ & 3793.15 & 3375.90 & \multirow{3}{*}{2220.40} & \multirow{3}{*}{1645.14} & 1.51 & 2.05 \\
\hline & & $\mathrm{F}_{2}$ & 3609.73 & 3212.66 & & & 1.44 & 1.95 \\
\hline & & $\mathrm{F}_{3}$ & 3409.35 & 3034.32 & & & 1.36 & 1.84 \\
\hline & \multicolumn{2}{|c|}{ Mean } & \multicolumn{2}{|l|}{3604.08} & & & 1.44 & 1.95 \\
\hline & \multirow{3}{*}{$\begin{array}{l}\mathrm{I}_{2}, \\
(55 \\
\%)\end{array}$} & $\mathrm{F}_{1}$ & 3380.65 & 3008.78 & \multirow{3}{*}{2169.76} & \multirow{3}{*}{1527.96} & 1.39 & 1.97 \\
\hline & & $\mathrm{F}_{2}$ & 3291.62 & 2929.54 & & & 1.35 & 1.92 \\
\hline & & $\mathrm{F}_{3}$ & 3123.00 & 2779.47 & & & 1.28 & 1.82 \\
\hline & \multicolumn{2}{|c|}{ Mean } & 3265.09 & & & & 1.34 & 1.90 \\
\hline & \multirow{3}{*}{$\begin{array}{l}\mathrm{I}_{3}, \\
(70 \\
\%)\end{array}$} & $\mathrm{F}_{1}$ & 3173.13 & 2824.09 & \multirow{3}{*}{2064.16} & \multirow{3}{*}{1449.84} & 1.37 & 1.95 \\
\hline & & $\mathrm{F}_{2}$ & 3039.31 & 2704.99 & & & 1.31 & 1.87 \\
\hline & & $\mathrm{F}_{3}$ & 2922.17 & 2600.73 & & & 1.26 & 1.79 \\
\hline & \multicolumn{2}{|c|}{ Mean } & 3044.87 & & & & 1.31 & 1.87 \\
\hline \multirow{12}{*}{$\begin{array}{l}\frac{\bar{c}}{0} \\
\frac{\mathrm{d}}{0} \\
\frac{\mathrm{d}}{1}\end{array}$} & \multirow{3}{*}{$\begin{array}{l}\mathrm{I}_{1}, \\
(40 \\
\%)\end{array}$} & $\mathrm{F}_{1}$ & 3911.33 & 3481.08 & \multirow{3}{*}{2336.41} & \multirow{3}{*}{1682.10} & 1.49 & 2.07 \\
\hline & & $\mathrm{F}_{2}$ & 3372.44 & 3001.47 & & & 1.28 & 1.78 \\
\hline & & $\mathrm{F}_{3}$ & 3099.37 & 2758.44 & & & 1.18 & 1.64 \\
\hline & \multicolumn{2}{|c|}{ Mean } & 3461.05 & & & & 1.32 & 1.83 \\
\hline & \multirow{3}{*}{$\begin{array}{l}\mathrm{I}_{2}, \\
(55 \\
\%)\end{array}$} & $\mathrm{F}_{1}$ & 3473.17 & 3091.12 & \multirow{3}{*}{2215.26} & \multirow{3}{*}{1526.26} & 1.40 & 2.03 \\
\hline & & $\mathrm{F}_{2}$ & 2998.89 & 2669.01 & & & 1.20 & 1.75 \\
\hline & & $\mathrm{F}_{3}$ & 2787.33 & 2480.72 & & & 1.12 & 1.62 \\
\hline & \multicolumn{2}{|c|}{ Mean } & 3086.46 & & & & 1.26 & 1.80 \\
\hline & \multirow{3}{*}{$\begin{array}{l}\mathrm{I}_{3}, \\
(70 \\
\%)\end{array}$} & $\mathrm{F}_{1}$ & 3164.08 & 2816.03 & \multirow{3}{*}{2101.94} & \multirow{3}{*}{1407.00} & 1.34 & 2.00 \\
\hline & & $\mathrm{F}_{2}$ & 2734.64 & 2433.83 & & & 1.16 & 1.73 \\
\hline & & $\mathrm{F}_{3}$ & 2529.84 & 2251.56 & & & 1.07 & 1.60 \\
\hline & \multicolumn{2}{|c|}{ Mean } & 2809.52 & & & & 1.23 & 1.78 \\
\hline
\end{tabular}

** Modified grain yield $\times 0.89=$ Modified dry grain yield $0.89=$ constant for the soft wheat. 


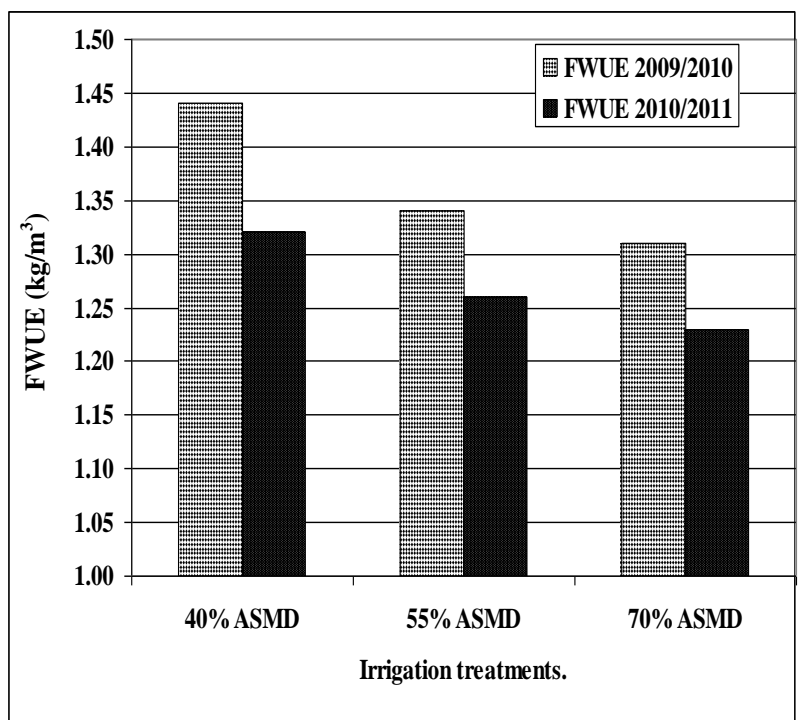

Fig. 3. Field water use efficiency of wheat crop under different irrigation treatments in both growing seasons.

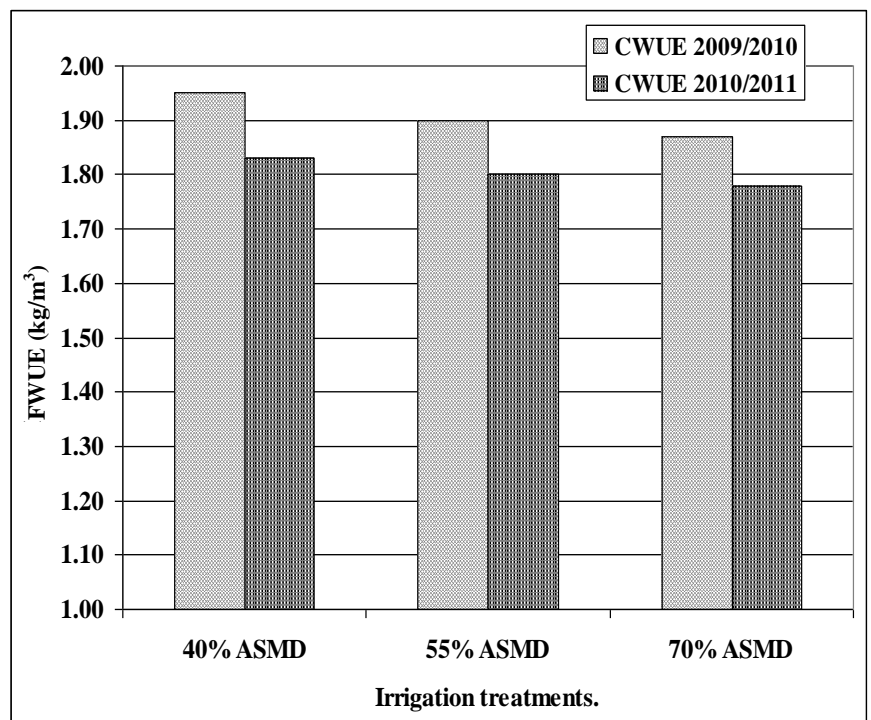

Fig. 4. Crop water use efficiency of wheat crop under different irrigation treatments in both growing seasons. 


\section{References}

Abou El-Soud, H.M. (2009) Studies on water and salt movement under surface drip irrigation systems in Nile Delta soils . M.Sc. Thesis , Fac. of Agric., Mansoura Univ., Egypt .

Badawy, W. (2001) Proceedings of the International Conference on Information Systems. Analysis and Synthesis, 2001, ISBN 980-07-7529-3.

Beshara, A.T. (2012) Effect of soil moisture depletion and nitrogen fertilizer application date on wheat yields, water and fertilizer use efficiencies in North Africa. Ph.D. Thesis, Institute of African Research and Studies, 2012, Cairo Univ., Egypt.

Dewis, J. and Fartias (1970) "Physical and Chemical Methods of Soil and Water Analysis", Soil Bulletin No. 10, FAO, Rome.

Downy, L.A. (1970) Water use by maize at three plant densities. Paper, 33, FAO , Rome.

Early, A.C. (1975) Irrigation scheduling for wheat in the Punjab. CENTO Scientific Programme on the Optimum Use of Water in Agriculture, Report No.17, Lyallpur, Pakistan, March, 3-5, pp. 115 - 127.

El-Desoky, M.A., Ghallab, A. and Teama, E.A. (2000) Efficient use and uptake of nitrogen for wheat yield in a clay soil in relation to split nitrogen application. Assiut J. Agric. Sci., Fac. of Agric., Egypt. 31(5): 153 - 167

El-Refaie, M. M. A., Badawi, A. Y., Tawadros, H. W., Hassanien, M. and ElSabbagh, A. A. (1988a) Effect of water regime and nitrogen fertilizer on maize production and its consumptive use. Proceeding of the Conference of Field Irrigation and Agro-Climatology, June 1988, Giza, Egypt.

FAO, Statistical Yearbook $(2005-2010)$.

Gad El-Rab, G. M., Ainer, N. G. and Eid, H. M. (1988) Water stress in relation to yield of wheat and some water relations in wheat . Egypt. J. Soil Sci. 28 (4): 433 - 445.

Garcia,G. (1978) "Soil-Water Engineering Laboratory Manual", Colorado State Univ., Dept.of Agric.and Chemical Engineering, Fort Collins, Colorado.

Hesse, P.R. (1971) "A Text Book of Soil Chemical Analysis", Juan Murry ( Publisher) Ltd, London.

Israelson, O. W. and Hansen, V. E. (1962) "Irrigation Principles and Practices", $3^{\text {rd }}$ ed., John Willey \& Sons Inc.,New York.

Jackson, M.L. (1967) "Soil Chemical Analysis", Printic-Hall of India, New Delhi.

Klute,A. (1986) "Methods of Soil Analysis" part 1, $3^{\text {rd }}$ ed., American Society of Agron., Inc. Madison, Wisconsin, USA.

Egypt. J. Soil Sci. 53, No.2 (2013) 
Lei Yan, Zhang Fu Cong, Kou Wen Ping and Feng Lei Lei (2010) Effect of water deficit at different growth stages and nitrogen fertilizer on yield and water use efficiency of winter wheat . J.of Northwest $A \& F$ Univ., Natural Science Edition, China, 38 (5) : 167 - 174.

Mahamed, M.B., Saborol, E., Tilahun Hordofa, Kaewrueng, S. and Verawudh, J. (2011) Effects of soil moisture depletion at different growth stages on yield and water use efficiency of bread wheat grown in semi arid conditions in Ethiopia. Kasetsart Journal, Natural Science, Kasetsart Univ. Res. and Development Ins. (KURDI). 45 (2): $201-208$.

Morsi, T.M.A. (2005) Development of farm irrigation, development of irrigation systems by adding fertilizer with irrigation water. Ph.D. Thesis, Fac. of Agric., Kafr ElSheikh, Tanta University.

Naeem Mahmoud Ahmed, R.N. (2005) Determination of water requirements and response of wheat to irrigation at different soil moisture depletion levels. International J.of Agric. and Biology. Friends Science Publishers. 7 (5) : $812-815$.

Pitts, D.J. (1997) “Evaluation of Micro-Irrigation Systems". South-West Florida Res. And Education center, Florida Univ. , Rainbird Tech-Tips , 5- Evaluation of Drip Systems.

Richards, L.A. (1954) Diagnosis and improving of saline and alkaline soils. U.S., Salinity Laboratory Staff., Agric. Handbook, No. 60.

Said, M. M. A. (1989) Effect of water stress, nitrogen fertilization and soil conditions on water requirements of corn, wheat, soybean and lentil in North Delta region. Ph.D. Thesis, Fac. of Agric., Alex. Univ., Egypt.

Saied, M. M. (1986) Effect of irrigation and fertilization on chemical composition and yield of wheat. M.Sc. Thesis, Fac. of Agric., Mansoura Univ., Egypt.

Sheikh, Z. I. and Gillani, S.N.A. (1990) Effect of farmer's irrigation practices on wheat yield: a case study with private tube well as a source of irrigation. Soil physics: application under stress environments, Proceedings of the International Symposium on Applied Soil Physics in Stress Environments, PARC, pp. 286 - 295, Islamabad, Pakistan.

Tariq Jan, Jan, M.T., Muhammad Arif, Habib Akbar and Sajid Ali (2007) Sarhad J. of Agric., NWFP Agric. Univ. 23 (4) : 871 - 879.

Vomocil, J. A. (1957) Measurements of soil bulk density and penetrability. A Review of Methods Adv.Agron. 9: 159-176.

(Received 28/8/2013;

accepted 7 /12/2013) 


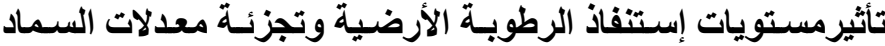

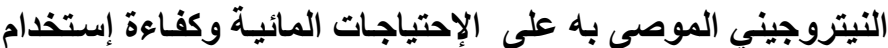 المياة لمحصول القمح في شمال الالتا لتاجيات}

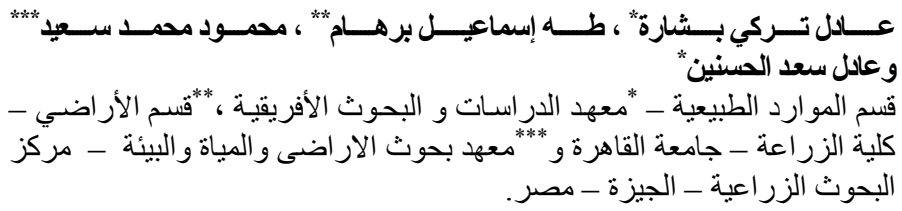

تم إجر اء تجربة حقلية في مزر عة محطة البحوث الزر اعية بسخا ـ محافظة كفر

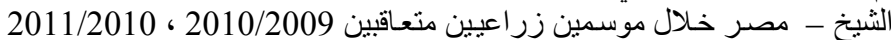

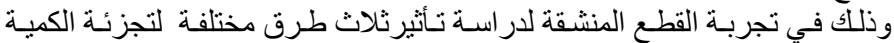

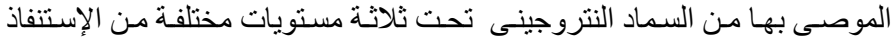

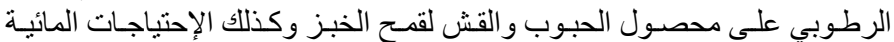

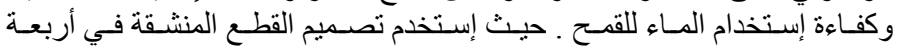

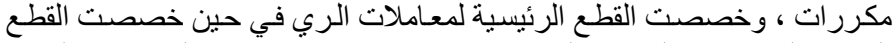

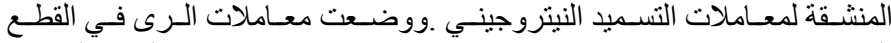
الرئيسـية وهـى (

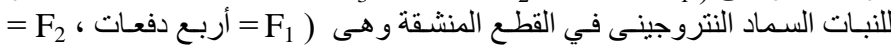

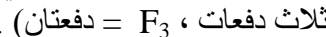

أظهرت النتائج أن قيم الإستهلاك المائى هو 1645,1 و 1528,0 1582 1

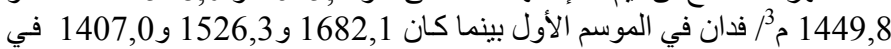

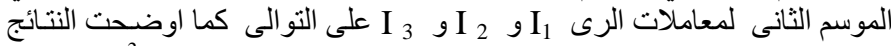

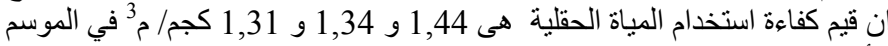

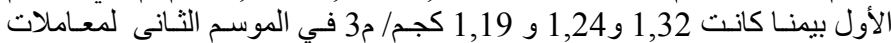

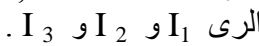

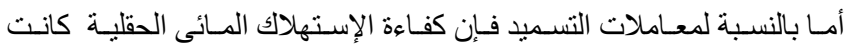

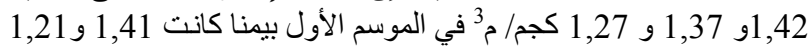

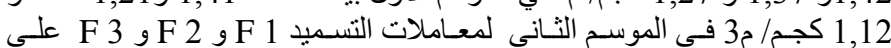

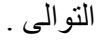

في ضوء النتائج السـابقة يمكن إستنتاج أن المعاملة

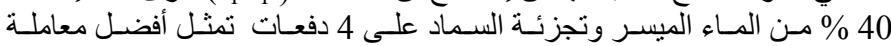
لمحصول القمح في شمال الدلتا . 